\title{
Color pattern variation in Cichla temensis (Perciformes: Cichlidae): Resolution based on morphological, molecular, and reproductive data
}

\author{
Paul Reiss ${ }^{1}$, Kenneth W. Able ${ }^{2}$, Mario S. Nunes ${ }^{3}$ and Tomas Hrbek ${ }^{3}$
}

\begin{abstract}
Morphological variants of Cichla temensis, readily differentiated by their striking color pattern differences, are found in several Amazon basin flood pulse river systems. The adult variants have at times been thought to represent different species or sexual dimorphism. A three part study was performed in two regions in Brazil (rio Igapó Açú and rio Caures) to elucidate the nature of the variants. In part one; selected diagnostic morphometric characters were compared intraspecifically among the variants and interspecifically with $C$. monoculus and $C$. orinocensis. All of the C. temensis variants were found to differ significantly from their sympatric congeners while not differing among each other. In part two, mitochondrial DNA samples were compared intraspecifically among the variants and interspecifically with their sympatric congeners. There were no diagnostic molecular synapomorphies that would unambiguously distinguish the variants and all $C$. temensis variants were clearly diagnosable and divergent from their sympatric congeners. In part three, color pattern variation in both sexes was compared to a gonadosomatic index (GSI). A significant correlation between color pattern variation and gonadosomatic index was found. The results of this study demonstrate that Cichla temensis variants are confirmed to be members of a single species and that the variation does not represent a sexual dimorphism. The color pattern variation is a cyclically occurring secondary sexual characteristic and is indicative of the specific degree of an individual's seasonal sexual maturation.
\end{abstract}

Variantes morfológicas de Cichla temensis, facilmente diferenciados por seus padrões de coloração marcantes, são encontrados em vários rios do sistema de inundação da várzea da bacia Amazônica. Variantes dos indivíduos adultos têm sido cogitados como pertencerem a uma diferente espécie ou apresentarem dimorfismo sexual. Um estudo em três etapas foi realizado em duas regiões no Brasil (rio Igapó Açú e rio Caures) para elucidar a natureza desta variação. Na primeira parte, caracteres morfométricos diagnósticos foram comparados intraespecificamente entre os variantes e interespecificamente com C. monoculus e $C$. orinocensis. Todos os variantes de $C$. temensis apresentaram diferenças significativas quando comparados com seus congêneres simpátricos enquanto não diferiram entre si. Na segunda parte, sequências de DNA mitocondrial foram comparadas intraespecificamente entre os variantes e interespeficamente com seus congêneres simpátricos. Não houve sinapomorfias moleculares diagnósticas para diferenciar inequivocamente os variantes e todos os variantes de $C$. temensis foram claramente divergentes de seus congêneres simpátricos. Na terceira parte, a variação no padrão de cor em ambos os sexos foi comparado ao índice gonadossomático (GSI). Foi encontrada uma correlação significativa entre a variação na coloração e o índice gonadossomático. Os resultados deste estudo demonstram que os variantes em Cichla temensis são membros de uma única espécie e que a variação não representa um dimorfismo sexual. A variação no padrão de cor é uma característica sexual secundária que ocorre em ciclos, sendo um indicativo do grau de maturação sexual sazonal dos indivíduos.

Key words: Gonadosomatic index, Mitochondrial DNA, Neotropical fish, Secondary sexual characteristics.

\section{Introduction}

The genus Cichla, Cichlidae, comprises 15 valid species (Kullander \& Ferreira, 2006) that are commonly known as peacock bass in English, tucunaré in Brazil and pavon in Spanish speaking countries (Kullander, 2003). They are large, diurnal predators and are primarily piscivorous (Jepsen et al.,
1997; Winemiller et al., 1997). The genus Cichla has historically been a subject of mixed taxonomic opinions (Stiassny, 1987). Recently, molecular analysis has provided clarification regarding its place in the family Cichlidae (Farias et al., 1999, 2000; López-Fernández et al., 2010) and a revision of Cichla has done much to resolve taxonomy within the genus (Kullander \& Ferreira, 2006). Cichla temensis has

\footnotetext{
${ }^{1}$ Rutgers University, Graduate Program in Ecology and Evolution, 14 College Farm Road, New Brunswick, New Jersey 08902. preiss@acuteangling.com

${ }^{2}$ Marine Field Station, 800 c/o 132 Great Bay Boulevard, Rutgers University, Tuckerton, New Jersey 08087. able@marine.rutgers.edu ${ }^{3}$ Universidade Federal do Amazonas (UFAM), Laboratório de Evolução e Genética Animal (LEGAL), Departamento de Biologia, ICB, 69077-000 Manaus, AM, Brazil.mariobiologia@hotmail.com; hrbek@evoamazon.net
} 
presented additional taxonomic questions at the species level, due to the existence of markedly differing color and pattern variants. Color and pattern changes have been described in many fishes within the family Cichlidae (Barlow, 2000) and specifically within the genus Cichla (Zaret, 1977; Winemiller, 2001; Kullander \& Ferreira, 2006). There has not, however, been an empirical clarification of the marked adult color and pattern variation within the species.

Cichla temensis is the largest species of the genus and is of significant economic importance in the lowlands of Amazonia, both as a sportfish (Myatt et al., 2005; Holley et al., 2008) and for human consumption (Smith, 1981; Goulding, 1996). The species occurs in blackwater flood pulse rivers with extremely variable seasonal environments (Val \& Almeida-Val, 1995). It is found in Brazil, Venezuela and Colombia from the rio Negro and rio Orinoco drainages, in Brazil in the rio Branco basin and in the lower rio Madeira basin (Kullander, 2003). Populations are also recorded in several blackwater tributaries of the rio Solimões and rio Amazonas (Kullander \& Ferreira, 2006).

In spite of its economic importance, study and management of Cichla temensis has been problematic in scientific, governmental and public domains. In comparison with many of its congeners who are readily accessible in less remote areas, the species has not been as extensively studied in its natural, flood pulse river habitat (Winemiller, 2001; Holley et al., 2008). The relative inaccessibility and complex physical and hydrological nature of the Amazon River basin have, until recently, made field collection and life history analysis of $C$. temensis difficult. Confusion caused by markedly different morphological variants has often led to those variants being identified as entirely different species by government agencies and the sportfishing community (Winemiller, 2001). Sound future management of this valuable species will benefit from a clear understanding of the nature of these variants.

Although the described variation in color pattern in this species occurs as a continuum (Winemiller, 2001), the common names used to describe these patterns are based on the two distinct extremes (Fig. 1a). The more brightly colored variant is known within the English-speaking sportfishing community as the three-barred peacock bass (Myatt et al., 2005) and in Brazil as tucunaré açu (Kullander, 2003). Its general body color is yellowish-gold, with brightly colored fins and a pattern of three sharply demarcated dark vertical bars on the trunk. (Fig. 1a, Grade 4). The other extreme, called the speckled peacock bass or tucunaré paca, is dark and cryptically colored. Its mostly grey or brown body is dappled with a prominent series of light spots but the bright colors are absent. The three vertical bars are faint or almost invisible in relation to the spots and background color. (Fig. 1a, Grade 1).

Although much current scientific literature suggests a single species, it has long been thought, and continues to be suggested by some, that these two clearly discernable "types" or "variants" are two separate species or subspecies. As a result, this taxonomic issue is relevant to management of the species. It is evidenced by an array of earlier scientific names (Kullander, 2003), varying non-scientific nomenclature and regulations used by governmental agencies and non-governmental organizations (Embratur, Roraima Fish Chart, Myatt et al., 2005) as well as descriptions in earlier publications (Smith, 1981). In contrast, other publications have proposed that the variation results from sexual dimorphism, i.e., that the brighter açu variants are sexually mature males and the darkly colored paca variants are immature forms or females (Braga, 1953; Kullander \& Ferreira, 2006). These unresolved explanatory theories of separate species or sexual dimorphism are taken together to serve as the null hypotheses for this study.

The alternate hypothesis that was explored in this study was suggested by behavioral observation of wild specimens. Despite being an indirect measure, behavioral observations are satisfactory tools for the suggestion of hypotheses, which can then be experimentally tested (Rohwer \& Rohwer, 1978). The principal difference observed between the color pattern variants centers around their reproductive behavior. Only fish of the brightly colored açu variant (Fig. 1a, Grade 4) have been observed engaged in either spawning or rearing activity. Although they build large nests and the attendant spawning fish are clearly visible from the surface, no fish of the paca variant (Fig. 1a, Grade 1) have been noted on any of an estimated three hundred undisturbed nests viewed (various professional fishing guides and P. Reiss, pers. obs.). After nesting, and once fry become free swimming, fry-guarding parental pairs are particularly susceptible to capture by angling. Prior to and during specimen collection for this study, many fry-guarding adults were captured and released, all of which were observed only in the açu form (various fishing guides and P. Reiss, pers. obs.). Paca variants have not been observed in these reproductively related activities.

These observations suggest the alternate hypothesis that the $C$. temensis variants are a single species and that color pattern variation (CPV) in Cichla temensis occurs within individuals of both sexes in relation to the reproductive cycle. Some publications (Winemiller, 2001; Willis et al., 2007) have noted similar observations and reflect the hypothesis explored herein.

Morphometric characters, molecular data and the relationship between color pattern variation and reproductive status were considered to test these hypotheses. First, to test the hypothesis that the variation occurs in individuals of a single species, it was necessary to determine that the $C$. temensis variant specimens actually constitute a single species and are not members of other species. An array of morphometric measurements and meristic counts of characters were compared from specimens along the continuum of $C$. temensis color pattern variation and from specimens of C. monoculus (Fig. 1b) and C. orinocensis (Fig. 1c), two regionally sympatric congeners. Second, tissue samples from each group were collected and subjected to DNA analysis. All morphometric and molecular data were compared among the nominal $C$. temensis variants as well as interspecifically with the sympatric congeners. Finally, to determine whether color pattern variation in C. temensis is related to the reproductive cycle, we compared the Gonadosomatic Index (GSI) among specimens representing grades along the continuum of $C$. temensis color pattern variability. 


\section{Material and Methods}

Study sites. To ensure that results did not reflect unique local phenomena, two widely separated regions, with ostensibly separate breeding populations of Cichla temensis (Winemiller, 2001; Vasconcelos, et al., 2005) were used for collection of specimens for the study (Fig. 2). Region 1, the Igapó-Açú basin, is a blackwater tributary complex of the lower rio Madeira, consisting of four cyclically flooding rivers interlinked with a large flooded forest lake situated south of the rio Amazonas main stem. Specimens of Cichla temensis and Cichla monoculus were collected here over a four week period during September and October, 2006. Region 2 encompassed the cyclically flooding rio Caures, a blackwater tributary of the rio Negro, situated north of the rio Amazonas main stem. Specimens of Cichla temensis and Cichla orinocensis were collected in Region 2 over three weeks during November and December, 2006. The collection periods in each region were selected to coincide with the dropping water period of each region's flood pulse, prior to the advent of the seasonal rains, and coinciding with a period of increased reproductive activity (Jepsen et al., 1997; Winemiller, 2001; Gomiero \& Braga, 2004; Holley et al., 2008).

Collecting methods. Samples were collected by angling with artificial lures at a mobile sportfishing camp. Although, anglers changed weekly, the guides remained constant. The guides were trained in the study's specimen collection protocol and were furnished with the necessary materials to collect uniquely numbered, positively identified specimens of $C$. temensis with reviewable color pattern variation assessments. Simultaneously, locally available congeners (C. monoculus in the rio Madeira region and C. orinocensis in the rio Negro region) were also collected for morphometric and DNA comparison with the specimens of presumed C. temensis.

The fishing operation's policies prohibited sacrificing captured fish exceeding $650 \mathrm{~mm}$ SL and prohibited sacrificing any fry-guarding fish. This prohibition effectively excluded extremely large and post-spawning specimens from analysis. Adult $C$. temensis specimens greater than $300 \mathrm{~mm}$ standard length (SL), a size indicating sexual maturity (Jepsen et al. 1999), were collected in Region $1(\mathrm{n}=101)$ and Region $2(\mathrm{n}=$ 79). C. monoculus $(\mathrm{n}=7)$ and $C$. orinocensis $(\mathrm{n}=35)$ are sexually mature at smaller sizes (Correa, 1998; Chellappa, 2003a), therefore specimens smaller than $300 \mathrm{~mm}$ SL but greater that $200 \mathrm{~mm}$ SL were included for those species. Tissue samples from $C$. temensis specimens in each color pattern variation grade and from the sympatric congeners were collected in the field and preserved in 95\% ethanol for DNA analysis.

Definition of color pattern variation grades. Previous descriptions of $C$. temensis color and pattern have been based mainly on examination of preserved specimens. This analysis examined the wider range and subtlety of color and pattern variation $(\mathrm{CPV})$ visible with live or fresh specimens. CPV in presumed Cichla temensis occurs as continuous variation. In order to dependably categorize the degree of CPV of the $C$. temensis specimens, four readily differentiated CPV grades were defined along the continuum, providing a semi-quantitative metric for interpretation and application of statistical analysis (Fig.1). Because this study is intrinsically dependent on these characters, we have described in detail the characteristic color and pattern character suite associated with each of the defined CPV grades, following the format and terminology used in a recent revision of the genus (Kullander \& Ferreira, 2006).

Grade 1 (paca) corresponds to the dark, cryptically patterned speckled peacock variant (Fig. 1a, Grade 1). It is distinguished by a dark grey or brown background color with a prominent series of light spots, typically arranged in four loosely delimited horizontal rows. There may be a total absence, ranging to a trace, of gold/brass coloration just beginning to appear on the lower edges of the interoperculum and suboperculum as well as the trunk just above the pelvic fins. The dorsal and upper caudal fins are dark grey or brown with white spots, recapitulating the body pattern. The pelvic, anal, and lower caudal fins are dark brown, ranging to dark red. Postorbital markings and dark vertical bars 1, 2, and 3 on the lateral body, although present, are rendered almost invisible by the dark background of grey/brown coloring.

Grade 2 (semi-paca) is distinguished by the appearance of significant gold/brass color radiating from the lower edges of the interoperculum and suboperculum and extending into the preoperculum and operculum (Fig. 1a, Grade 2). Noticeable gold/brass coloration extends into the body, encompassing the pelvic fins and the ventral lateral region anterior to vertical bar 2 . The dorsal and posterior trunk remains a darker grey or brown. The upper fins remain dark while the lower fins become recognizably red. The black vertical bars 1,2, and 3 are visually equal in prominence to the background of lighter lateral spots. The postorbital markings on the operculum emerge from the dark background and their pattern is now distinguishable.

Grade 3 (semi-açu) specimens are defined by a trunk dominated by gold/brass color below and extending to the lateral line (Fig. 1a, Grade 3). The upper fins remain dark while the lower fins become a lighter, brighter red. The black vertical bars become visibly dominant on the trunk. The pattern of light lateral spots remains visible, although its contrast against the mostly gold trunk is diminished. The postorbital markings on the operculum are clearly visible.

Grade 4 (açu) corresponds to the brightly colored threebarred peacock variant (Fig. 1a, Grade 4). The entire lateral body is a bright yellowish-gold color except for the dorsal extremes. The dorsal fins and upper portions of the caudal fin show a blue cast, ranging up to a bright, electric blue. The pelvic, anal and lower portions of the caudal fins are bright red to reddish orange. The vertical black bars 1,2, and 3 are sharply demarcated and dominate the lateral pattern. The light spots on the body are essentially absent, although traces may remain visible. The postorbital markings are sharp and distinct.

Treatment protocols. In order to standardize identification of the different grades, all live specimens were photographed 
by guides promptly after capture using compact digital cameras (Olympus Digital Zoom, 2.1 megapixels). Specimen color patterns were assessed against a waterproof CPV chart and the Grade 1-4 descriptions. An identifying waterproof numbered tag was placed in the specimen's buccal cavity for subsequent identification. The specimen was then delivered to the field laboratory for treatment. In order to confirm the accuracy of initial grading and to ensure correct identification of each individual, specimens were re-photographed using a high-resolution digital camera (Nikon D200, 10.3 MP) and then re-graded by two other individuals at the time of dissection. Individual C. temensis possess an irregular postorbital stripe comprised of a variable series of black markings on the operculum (Kullander \& Ferreira, 2006). These markings are effectively unique to individuals and useful for identification. All photographs were taken in a uniform fashion allowing the postorbital markings on the left operculum to serve as a second confirmation of positive sample identification between capture and field measurements.

Morphometric and meristic measurements. Following photographic recording and assessment of CPV grade, an array of morphometric measurements were taken for all specimens, including congeners of $C$. temensis. The characters recorded included; ray counts for first and second dorsal, caudal, anal, pelvic and pectoral fins; scale counts circumpeduncular, predorsal, on lateral line, above and below lateral line; gill raker counts; measurement of standard length, eye diameter, head height, maximum height, premaxilla to opercule and girth; weight of entire specimen, liver, stomach, and gonads. The measurements were made using American Fisheries Society techniques (Schreck \& Moyle, 1990; Murphy $\&$ Willis, 1996) and were analyzed for the purpose of identifying the most useful, taxonomically diagnostic, species specific characters for this study and to determine if any significant differences existed among the $C$. temensis variants. Digital electronic calipers (Avenger Digital Caliper) were used for all measurements except standard length, where an analog mechanical caliper was used (Aluminex). Certain morphometric and meristic characters have been shown to be diagnostically useful for identification purposes within Cichla (Lasso \& Machado-Allison, 2000; Kullander \& Ferreira, 2006), including lateral line scale count, height:standard length (SL) ratio and relative eye diameter. Since eye diameter can have an allometric component, we concentrated on the other two characters. Scale counts were made for all specimens of all species. The majority of $C$. temensis specimens possess continuous lateral lines (Kullander \& Ferreira, 2006). In the case of specimens with discontinuous lateral lines, counts were made following the same pattern of scale rows as in complete lines. Total specimen weight was measured on a precision digital scale and recorded to the nearest gram.

Gonadosomatic index. Upon completion of the above measures, all specimens were weighed (Sartorius model GE7101, precision 0.1 gram) then dissected to determine reproductive characteristics. Testes and ovaries were weighed on a digital scale to within 0.1 gram. Reproductive status was assessed by the Gonadosomatic Index [GSI = 100(wet wt gonads in $\mathrm{g}$ )/(total body wet wt in g- wet wt gonads in g)] (Le Cren, 1951). Gonads were examined microscopically to confirm sex determination. Egg size and maturity were examined (anecdotally, for the purpose of observing the relationship between GSI and gamete maturity) by microscopic examination of dissected ovaries (Baytronix x20 trinocular stereo microscope with eyepiece reticule). Photomicrographs of eggs, sperm, and gonadal tissues were made using a high-resolution digital camera body mounted on the trinocular head (Nikon D100 and D200, 10.3 megapixels).

Molecular methods. In addition to the data analyzed on-site in this study, mitochondrial DNA variation for specimens of each color variation grade and extremes of paca $(n=22)$ and açu $(n=28)$, as well as for samples of the other species, was examined at the Universidade Federal do Amazonas. DNA extraction was performed using the protocol described in Sambrook et al. (1989). We chose to analyze the mitochondrial control region because it is generally found to have the highest substitution rate in the mitochondrial genome (e.g. Donaldson et al., 1999), and mitochondrial DNA has a high rate of coalescence due to its (hypothetically) strictly-maternal inheritance in comparison to the nuclear genome (Hudson \& Coyne, 2002). Therefore, the sharing of haplotypes and lack of reciprocal-monophyly at this locus would be highly indicative of ongoing gene exchange between the paca and açu phenotypes.

The mitochondrial control region was amplified via PCR using primers LProf (5' AACTCTCACCCCTAGCTCCCAAAG3') (Meyer et al., 1994) and primer 12SR5 (5'GGCGGATACTTGCATGT-3') (Farias \& Hrbek, 2008). For the amplification of each sample we used $0.8 \mu \mathrm{L}$ of DNA (approximately $30 \mathrm{ng}$ ), $2 \mu \mathrm{L}$ of each $2 \mu \mathrm{M}$ primer, $2.5 \mu \mathrm{L}$ of buffer (200 mM Tris-KCl, pH 8.5), $1.5 \mu \mathrm{L} 25 \mathrm{mM} \mathrm{MgCl}, 2.5 \mu \mathrm{L}$ of 10 $\mathrm{mM}$ dNTP, $0.2 \mu \mathrm{L}$ of Fermentas Taq polymerase enzyme (5U/ $\mu \mathrm{L})$ and $13.5 \mu \mathrm{L}$ of $\mathrm{ddH}_{2} \mathrm{O}$ in a final reaction volume of $25 \mu \mathrm{L}$. The PCR reactions were performed under the following cycling conditions: 35 cycles consisting of 1 minute at $92^{\circ} \mathrm{C}$ (denaturation), 35 seconds at $50^{\circ} \mathrm{C}$ (annealing of primers) and 1 minute at $72^{\circ} \mathrm{C}$ (primer extension) and final extension at $72^{\circ} \mathrm{C}$ for 5 minutes. The PCR products were subjected to purification by precipitation with sodium acetate (3 M, pH 4.8) and 95\% ethanol, and resuspended in $25 \mu \mathrm{L}$ of $\mathrm{ddH}_{2} \mathrm{O}$.

The sequence reactions were performed in a final reaction volume of $10 \mu \mathrm{L}$ using the DYEnamic ${ }^{\mathrm{TM}} \mathrm{ET}$ dye terminator kit (GE-Healthcare). Each reaction had the following composition: 4 $\mu \mathrm{L}$ of amplified DNA, $2 \mathrm{~L}$ of $2 \mu \mathrm{M}$ primer, $2 \mu \mathrm{L}$ of ET-terminator and $2 \mathrm{~mL}$ of $\mathrm{ddH}_{2} \mathrm{O}$. The samples were then subjected to a 35 cycle thermocycling protocol with the following temperature profile: 20 seconds at $95^{\circ} \mathrm{C}$ (denaturation), 15 seconds at $55^{\circ} \mathrm{C}$ (primer annealing) and 1 minute at $60^{\circ} \mathrm{C}$ (primer extension). At the end of the PCR reaction, samples were purified via $3 \mathrm{M} \mathrm{NaOAc/}$ Ethanol precipitation, and resuspended in $10 \mathrm{~mL}$ MegaBACE loading solution ( $70 \%$ formamide/ $1 \mathrm{mM}$ EDTA mix) according to 


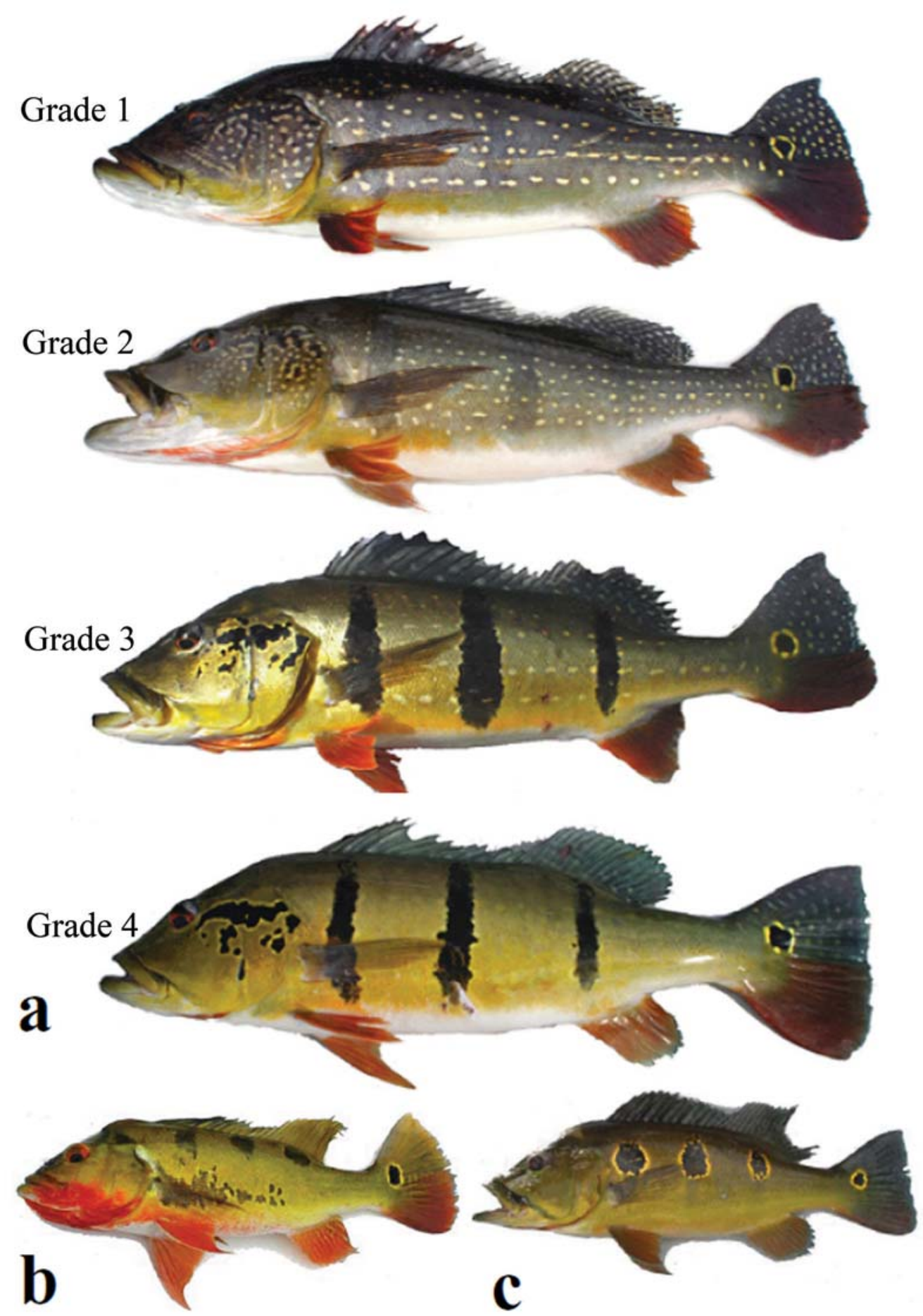

Fig. 1. a) Four defined color pattern grades in Cichla temensis used to group live specimens in the field. Specimens within each grade occur along a continuum of color and pattern variation. Grades 1 and 4 represent the extremes of variation. The more brightly colored Grade 4 (specimen $\mathrm{TL}=548 \mathrm{~mm}$ ) variant is known as the three-barred peacock or tucunaré açu in Brazil. At the other extreme, Grade 1 (specimen TL $=541 \mathrm{~mm}$ ) is known as the speckled peacock or tucunaré paca and is dark and comparatively non-descript. Grade 2 (specimen $\mathrm{TL}=613 \mathrm{~mm}$ ) and Grade 3 (specimen $\mathrm{TL}=585 \mathrm{~mm}$ ) represent transitional degrees of variation between the extremes of paca and açu. All variant grades were collected in both Region 1 and Region 2 (Fig. 2); b) Cichla monoculus was collected in Region 1 (specimen TL $=382 \mathrm{~mm}$ ) and displays a pattern of bars 1, 2 and 3 similar to, but shorter than those of $C$. temensis without postorbital markings but with an abdominal bar; c) Cichla orinocensis was collected in Region 2 (specimen $\mathrm{TL}=412 \mathrm{~mm}$ ) and is differentiated by three ocellar marks in place of vertical bars 1,2 and 3 . Postorbital markings are absent. 
manufacturer's instructions (GE-Healthcare). Subsequently, the samples were electro-injected and the sequences were resolved on an automatic sequencer MegaBACE 1000 DNA Analysis System (GE-Healthcare) following manufacturer's instructions. The sequences were manually edited and aligned by hand in the program BioEdit (Hall, 1999).

Data Analysis. Analyses of all morphological data were calculated using SPSS version 16.0 and Microsoft Excel. Analysis of variance of morphometric parameters between the variants was performed by ANOVA followed by post hoc t-test on this data. Differences in morphological parameters between C. temensis variants and other species were analyzed using two sample t-tests and ANOVA. Specimen height to standard length ratio $(\mathrm{H} / \mathrm{SL})$ is affected by the variable size of individual specimen's gonads. A girth to length ratio factor was calculated and applied to H/SL values as a specimen specific adjustment for varying reproductive state. The relationship between CPV and GSI was determined using the Spearman rank order correlation coefficient for non-parametric correlations.

We performed two types of molecular analysis on nominal C. temensis specimens. First we tested if the açu and paca phenotypes were monophyletic. Monophyly and diagnostic characters are a premise of the phylogenetic species concept (Mayden, 1997), and the majority of biological species are apparently monophyletic (Avise, 2000), although a review by Funk \& Omland (2003) suggests that up to approximately $24 \%$ of the surveyed fish species may be non-monophyletic. We ran a constrained maximum-likelihood search under the HKY85 model of molecular evolution (Hasegawa et al., 1985), and tested if the most likely constrained phylogeny was a significantly worse phylogenetic hypothesis than an unconstrained phylogeny using the approximately unbiased test of Shimodaira

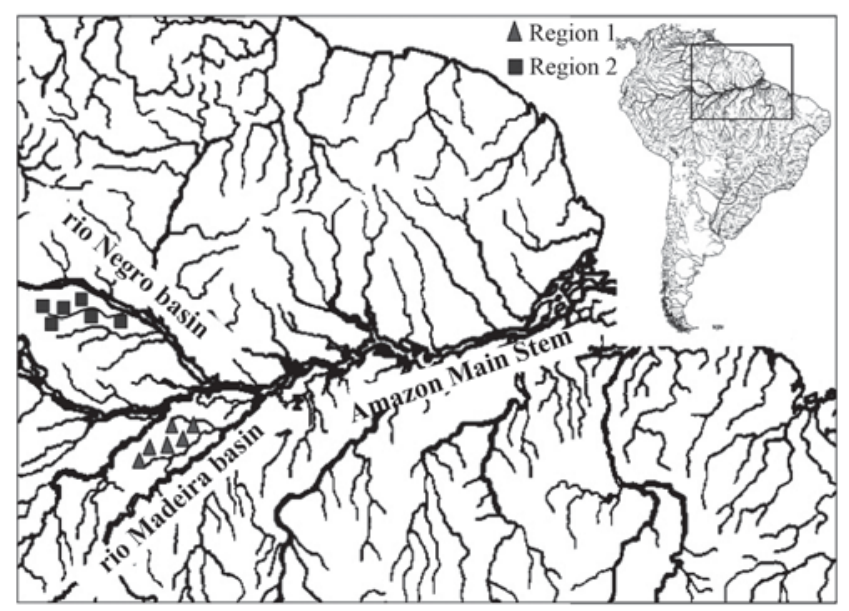

Fig. 2. Collecting regions in two cyclically flooding drainages in the rio Amazon basin. Region 1, the Igapó-Açu region, a blackwater tributary complex of the rio Madeira, provided specimens of $C$. temensis and C. monoculus. Region 2, the rio Caures, a blackwater tributary of the rio Negro, provided specimens of $C$. temensis and C. orinocensis.
(2002). Phylogenies were rooted with species of the clade A Cichla species (sensu Willis et al., 2010) available in GenBank (HQ230011 - HQ230016) of which C. temensis is a nested member, and thus represented potentially the best outgroup taxa. The outgroup species were $C$. jariina, $C$. piquiti, $C$. melaniae, $C$. mirianae, C. pinima, $C$. thyrorus, $C$. vazzoleri, and $C$. kelberi. Tests were implemented in the program Treefinder (Jobb et al., 2004) and the model of molecular evolution was selected with ModelTest (Posada \& Crandall, 1998) using the Akaike Information Criterion. Recently diverged species may not be monophyletic, but because of lack of genetic exchange, should differ in haplotype frequencies (Avise, 2000). Therefore, we tested if the sequences observed in the açu and paca phenotypes were sampled from the same pool of haplotypes using an Analysis of Molecular Variance implemented in the program Arlequin 3.5.1.2 (Excoffier \& Lischer, 2010). Inference of species-level differences and the number of molecular synapomorphies for the paca and açu phenotypes were inferred using the methodology of Davis \& Nixon (1992).

\section{Results}

Comparisons between the $C$. temensis variants and their sympatrically occurring congeners found morphometric differences (Fig. 3). ANOVA of lateral line scale counts for $C$. temensis, C. monoculus, and $C$. orinocensis showed that the species were significantly different. Post hoc t tests demonstrated that each of the species were significantly different from each other; $C$. temensis and $C$. monoculus, $\mathrm{t}(6)=$ $11.00, \mathrm{p}<.0001 ;$ C. temensis and C. orinocensis, $\mathrm{t}(43)=33.08$, $\mathrm{p}<.0001 ; C$. monoculus and $C$. orinocensis, $\mathrm{t}(8)=6.25 \mathrm{p}=$ 0.0002 . These results were similar to previously published data and support their descriptions as different species (Lasso \& Machado-Allison, 2000; Kullander \& Ferreira, 2006). No diagnostically useful, significant differences were found in any of the other measured parameters. Genetic divergence between the Cichla temensis variants and the other Cichla species was estimated to be 8.8-13.0\% p-distance (Fig. 4), and there were 46 molecular synapomorphies that unambiguously distinguished C. temensis from all other Cichla species of the clade A (sensu Willis et al., 2010). Cichla temensis is also distinguishable by these 46 and additional synapomorphies from the sympatrically occurring $C$. monoculus and $C$. orinocensis, since $C$. monoculus and $C$. orinocensis both occur in the clade B of Cichla species (sensu Willis et al., 2010).

With the exception of visible nuchal humps found in some male specimens of $C$. temensis, as described in Gomiero \& Braga (2004), no significant differences, including differences in scale counts and relative body depth, were found among the color pattern variants. Nor do any of the other measured morphometric characters differentiate any of the variants from each other. The constrained maximum-likelihood phylogenetic hypothesis assuming monophyly of the açu (Grade 4) and paca (Grade 1) phenotypes was a significantly worse explanation of the data than the unconstrained most likely phylogeny $(p=0.0384)$, 
rejecting the hypothesis that the açu and paca phenotypes form monophyletic entities. Analysis of molecular variance also indicated the açu and paca sequences were sampled from the same gene pool $(\mathrm{p}=0.0605 \pm 0.0025)$, and show no difference in haplotype frequencies between themselves. Furthermore, there were no molecular synapomorphies that would differentiate the açu and paca phenotypes. The molecular tests reflect extensive sharing of haplotypes between the full range of CPV grades. All intraspecific comparisons indicate that the variants are individuals of a single species.

Gonadosomatic index values increased in both males and females as color pattern variation grade progressed from the paca form (Grade 1) through the açu form (Grade 4), revealing a significant positive correlation between GSI and CPV in both sexes and in both study regions (Fig. 5). Females showed a higher correlation than males. Female specimens from the Igapo-Acu had a Spearman's rho $=0.833 ; \mathrm{P}=<.0001$ while those from the rio Caures had a Spearman's rho $=0.784 ; \mathrm{P}=<$ 0.0001 . Males from the Igapó-Açú had a Spearman's rho $=$ $0.666 ; \mathrm{P}=<0.001$ while those from the rio Caures also showed a significant correlation between GSI and CPV Grade, Spearman's rho $=0.589 ; \mathrm{P}=<0.0015$.

The GSI values for both males and females in both regions rose most abruptly at grades 3 and 4 , with Grade 4 having the highest mean value (Fig. 5). In addition, there was a consistently visible relationship between the grade assigned and the morphology and maturity of the gonads in both sexes. Although ovaries did not increase in length, they increased in relative thickness as they increased in weight. Ovary weights varied from 0.5 grams to 42.9 grams. Grade 1 females had the lightest and thinnest ovaries. Microscopic examination of ovaries from Grade 1 individuals, regardless of the specimen's size, showed only immature oocytes, with no mature eggs. Ovaries from Grade 2 individuals were also immature, although the mean relative ovary size was greater. Grade 3 ovaries showed a marked increase in relative size, although variability was greater than in any other grade. Vitellinization was apparent in oocytes from the ovaries of Grade 3 individuals. Ovaries from Grade 4 individuals were largest. They were thick and distended and contained large (approximately $3 \mathrm{~mm}$ ) oval eggs. Testes ranged from 0.1 to 6.0 grams. Although testes were far smaller in relation to ovaries at every $\mathrm{CPV}$ grade, their relative weight increases were similarly proportional across the range of grades (Fig. 5). Thickness of the testes increased in a similar, but reduced, fashion to that of ovaries. Thus, overall coloration and pattern was not sexually dimorphic in the Cichla temensis variants. Males and females had the same changes in color pattern as their gonads developed, furnishing no visible, external means of distinguishing sex.

\section{Discussion}

The morphometric and genetic results of this study indicate that all of the variants of $C$. temensis are clearly differentiated from sympatric $C$. monoculus and $C$. orinocensis and that all of these species differ from each other. Moreover, these results
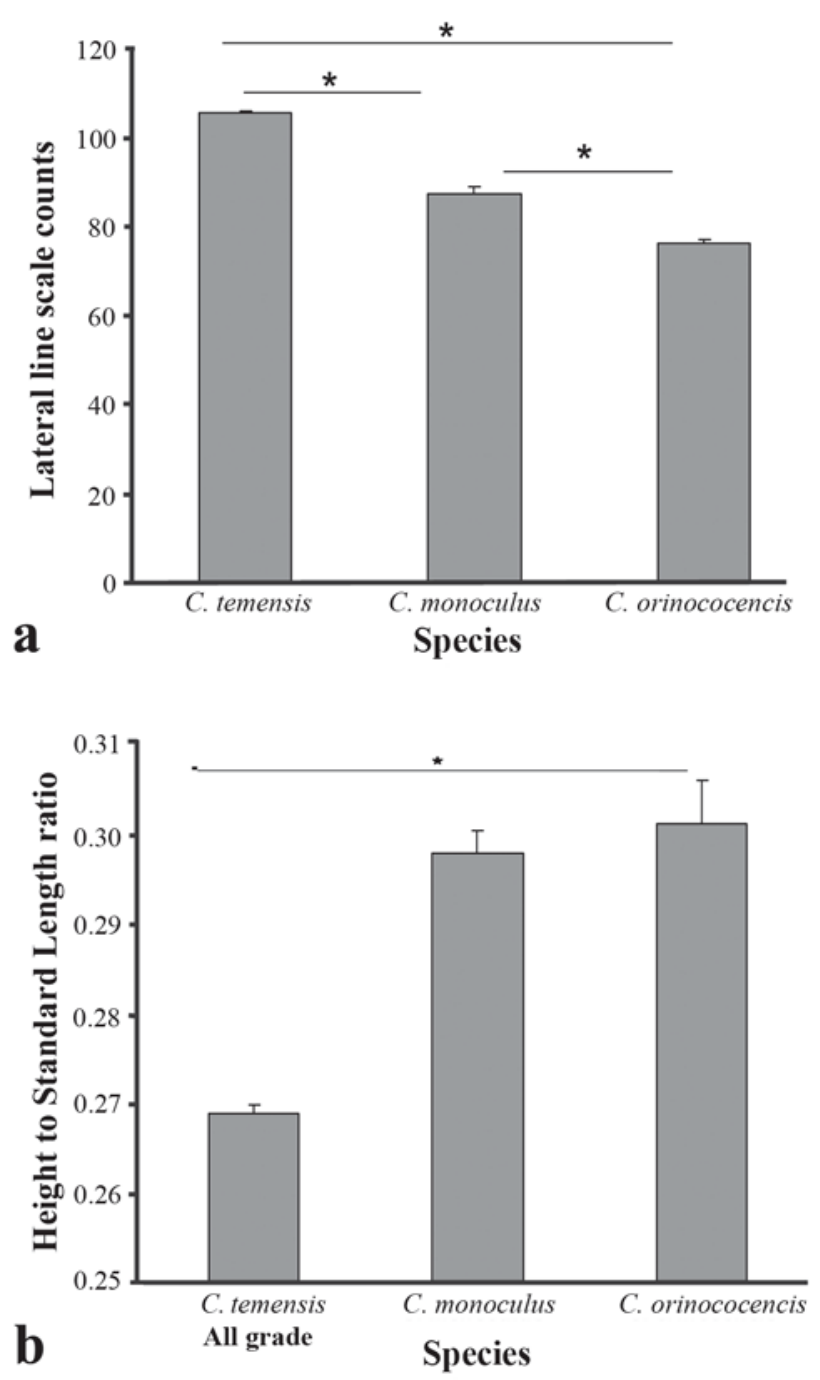

Fig. 3. a) Mean ( \pm SEM) lateral line scale counts for $C$. temensis, C. monoculus, and C. orinocensis. ANOVA showed no significant differences among the $C$. temensis variants but revealed significant differences interspecifically. Post hoc $t$ tests (horizontal starred bar) revealed that all species were significantly different, $\mathrm{p}<0.0001^{*}$. b) Mean ( \pm SEM) body depth to Standard Length ratio (adjusted for gonad size differential) for $C$. temensis, C. monoculus, and $C$. orinocensis. ANOVA showed no significant differences among the $C$. temensis variants but revealed significant differences interspecifically. Post hoc t tests (horizontal starred bar) revealed that all $C$. temensis were significantly different from both sympatric species, $\mathrm{p}<0.0001^{*}$.

confirm that the variants of $C$. temensis are a single species. Further, the CPV and GSI results imply that change in color pattern in C. temensis occurs in a cyclical fashion in individual fish. Since both sexes follow precisely the same progression of color pattern variation, $C$. temensis color pattern variation is neither a sexual dimorphism nor an external means of differentiating sex. Rather, it is a secondary sexual characteristic indicating 


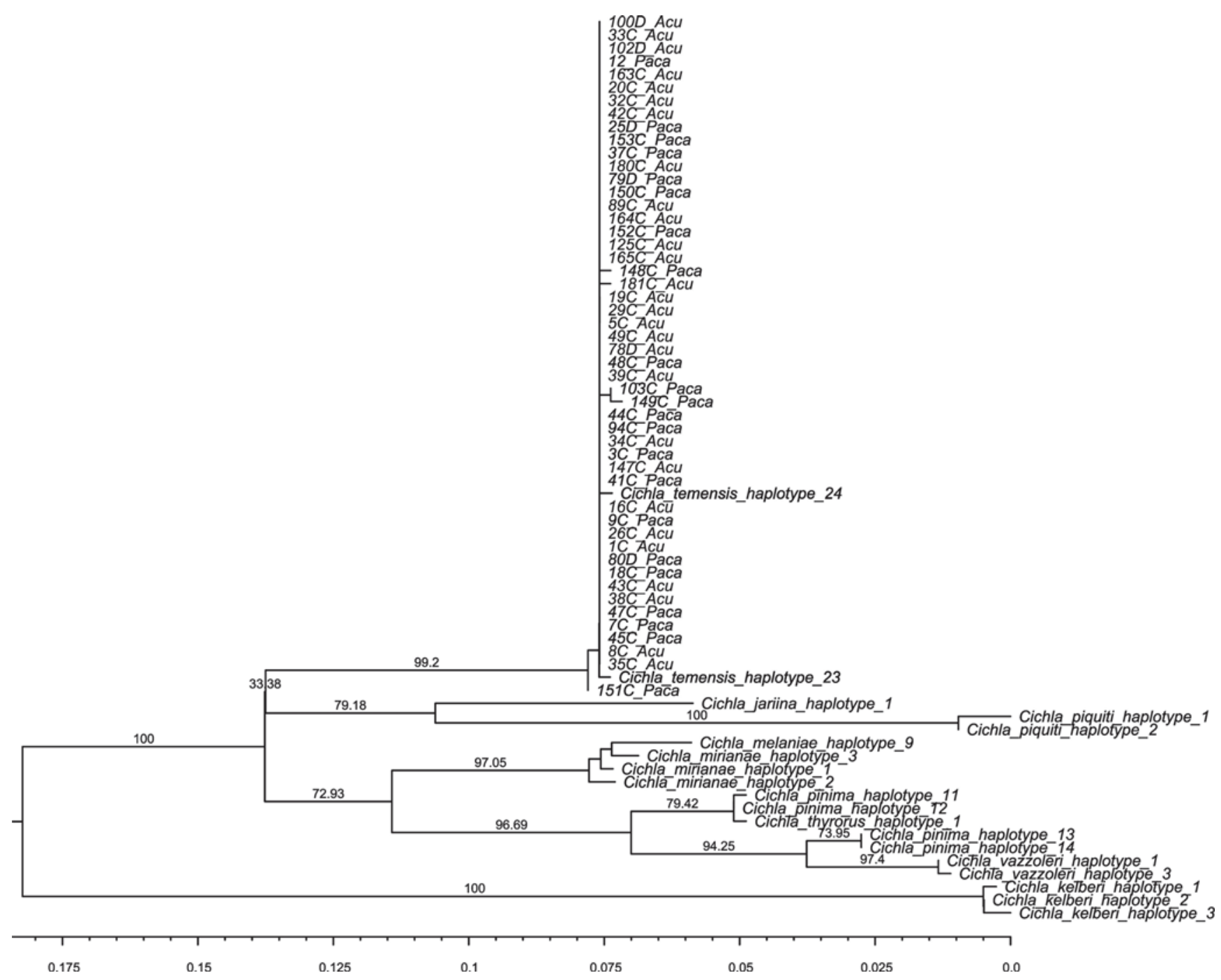

Fig. 4. Maximum-likelihood phylogeny of 50 sequences sampled from the paca and açu variants of Cichla temensis (Genbank accession numbers HQ230011 - HQ230016) The phylogeny was rooted a posteriori with Cichla species of the clade A (sensu Willis et al. 2010) (GU295691- GU295704). The scale represents an HKY85 genetic distance.

reproductive status in both sexes. Similar results in both of the study regions confirm that the results are not regional phenomena.

Although C. monoculus and C. orinocensis were treated in the same manner as $C$. temensis, no comparable variation in color pattern occurred in either sympatric species. Although some specimens' body coloration appeared brighter than others, no significant relationship was found between this coloration and their GSI. In several cases, however, and as noted by Munoz et al. (2006), C. monoculus displayed a bright orange coloration on its lower jaw, isthmus and operculum when GSI was high, while this coloration was absent or muted in specimens with low GSI.

Color and color pattern changes have been described in many other fishes, occurring in association with agonistic behavior, spawning behavior, maturation and sexual selection, including within the family Cichlidae (Barlow, 2000). Several authors have addressed color pattern changes in juvenile
Cichla during maturational stages. Zaret (1977) described ontogenetic color and pattern changes and showed that certain color pattern development inhibits cannibalism in C. ocellaris. Kullander \& Ferreira (2006) noted that a paca form occurs prior to first maturity in juveniles of several Cichla species other than C. temensis; however the observation in these species is that the paca pattern is lost altogether with increasing size. Winemiller (2001) described in detail the brightening coloration in breeding adults of several Cichla species, including $C$. temensis. This study, however, is the first to document that the conspicuous color and pattern changes occurring in both sexes in C. temensis are associated with seasonal maturity.

CPV Grade 1 and Grade 2 females consistently contained ovaries showing immature germ cells, inferred by Chellappa $e t$ al. (2003b) as "immature" stage. Ovaries from Grade 3 individuals showed partially developed eggs with significant vitellinization, and ovaries from Grade 4 individuals were 

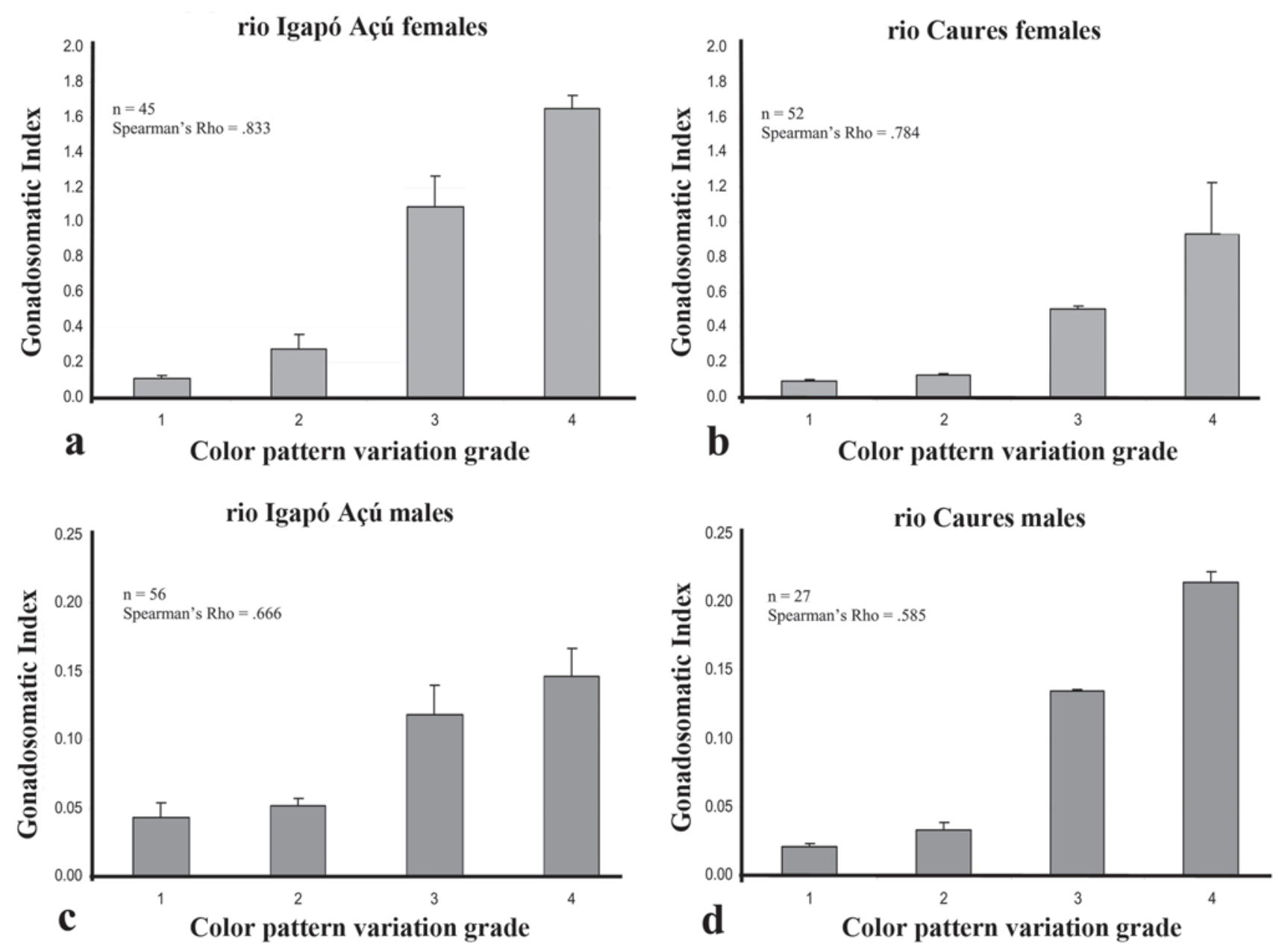

Fig. 5. Mean Gonadosomatic Index for C. temensis variants grouped by CPV grade. a) Females from the Igapó Açú (Region 1). b) Females from the rio Caures (Region 2). c) Males from the Igapó Açú region. d) Males from the rio Caures. A significant correlation between GSI and CPV Grade was found for males and females in both collecting regions, $\mathrm{p}<.01 \mathrm{for} a, \mathrm{~b}, \mathrm{~d}$, and d.

engorged with fully developed eggs apparently ready for deposition, stages denominated by Chellappa et al. (2003b) as "maturing" and "mature" stages, respectively. Since post spawn specimens were not sacrificed in this study, due to their fry-guarding status, no ovaries were examined showing vacant spaces or flaccid appearance, as in the "spent" stage inferred by Chellappa et al. (2003b). Gomiero \& Braga (2004) described stages of development in their studies of C. monoculus and $C$. ocellaris using a different maturity scale but indicating a similar progression of maturation.

The data collected in this study form a series of snapshots of $C$. temensis color pattern variation taken during dry season conditions. They are not a complete cyclical set spanning the rainy season. Effective sampling by angling is almost entirely restricted to low water conditions in Amazon flood pulse river systems (P. Reiss, personal observation). Collection of Cichla by other means is also more difficult in high water conditions (Rabelo \& Araujo-Lima, 2002). As a result, data of the type obtained by angling in this study is not as readily available from high water periods. Therefore, until a study is performed that observes individuals in the post-spawning condition, it cannot be known precisely how color pattern variation proceeds during the high water period and how individual açu (Grade 4) return to the paca (Grade 1) condition. Studies in artificial environments, however, may be inapplicable, since various species of Cichla have been shown to modify their behavior in reservoirs or other artificial environments (Zaret, 1980). Chellapa et al., (2003b) cite Brafield \& Llewelyn (1982) in noting that different environmental conditions can yield different reproductive strategies in Cichla.

In spite of the lack of data collected in high water, several considerations make it seem likely that the color pattern cycle proceeds in a similar, albeit reversed fashion after spawning and rearing is completed. Jepsen et al. (1999) indicate that it is likely that individuals spawn only once per year in flood pulse environments. The majority of $C$. temensis individuals spawn toward the end of the dry season, immediately preceding the onset of the rainy season (Jepsen et al., 1997; Gomiero \& Braga, 
2004). Preliminary data from a study in progress suggests that a greater percentage of $C$. temensis are caught by angling in the açu pattern during the lowest water levels of the dry season and that paca appear to be more plentiful when water levels are higher (P. Reiss, unpublished data). Together with the routine capture by angling of paca in all size ranges above $300 \mathrm{~mm}$ (including the largest, approaching $900 \mathrm{~mm}$ ), this information supports the likelihood of a reverse process returning açu variants to the paca form.

Many Amazon fishes have marked physiological plasticity enabling adaptation to highly variable environmental conditions (Val \& Almeida-Val, 1995). Since the environment of $C$. temensis changes drastically from its low to high water extremes (Sioli, 1984), it is likely that their cyclical color and pattern variation may have adaptive value.

For example, the bright açu coloration is highly visible to observers both under and above water and could plausibly increase fitness in several ways. As the flood pulse cycles into the dry season and water levels decrease, more shallow areas with submerged wood, suitable for spawning, become available and greater percentages of the $C$. temensis population begin entering the spawning cycle. Since the positive correlation between CPV and GSI found in this study indicates that the açu variants are physiologically more prepared to spawn than the paca variants, their bright coloration may provide a signal of spawning readiness to potential mates prior to pairing and nest building, as has been shown in other fishes and suggested for Cichlidae (Barlow, 2000). Following egg deposition and during fry guarding, it is possible that the brightly colored and highly visible açu color pattern of the parents acts as an aposematic signal to warn off egg or fry predators (Schroder \& Zaret, 1979; Rodrigues et al., 2009). Although C. temensis are neither ovophilic nor larvophilic mouthbrooders, both fishing guides and local residents have reported observing fryguarding parents gather their school of surface-feeding offspring and depart an area at signs of danger. A mechanism to prepare and concentrate fry would make such a tactic more effective and maximize survival of offspring, improving reproductive success, and thereby increasing fitness of the parents. During the period when fry are being guarded by one or both parents, the açu coloration and individually unique postorbital markings may provide a recognizable bonding pattern or signal of "safe haven" to the fry when warned by the parent. Warning signals to offspring during parental guarding (Shennan et al., 1994) and even delayed mouthbrooding (Goodwin et al., 1998) have been demonstrated in other Neotropical cichlids.

In contrast to the bright açu coloration, the dark background coloration of the paca closely resembles the color of the tannin stained water and submerged wood in the flooded forest (called "igapó" in Brazil), while the light spots on the body are reminiscent of the dappling effect of light penetrating the flooded forest structure. In Amazon flood pulse rivers, high water inundates the surrounding igapó and interfluvial marshes during the rainy season (Goulding, 1988; Junk, 1997). Small forage fishes are able to feed in the igapó (Forsberg, 2001) while finding shelter from predation (Marshall, 2007). A large predator such as C. temensis entering the dense concentration of flooded trunks, stems and leaves to pursue prey species may not be able to rely solely on the speed and stamina that enable it to hunt in open, low water conditions. The paca color pattern may enhance crypsis of foraging $C$. temensis in the flooded igapó environment, thereby improving hunting effectiveness, survival and consequently fitness.

Despite a plethora of studies worldwide that have demonstrated the socio-economic value of sport fishing (Vander Zanden et al., 2007; Jensen, 2009) and its sustainable nature, C. temensis remains subjected to mostly uncontrolled commercial harvest (Holley et al., 2008). Regulatory efforts at balancing the sport fishing and commercial value of the species in its native habitat have often been equivocal or ineffective. Anecdotal conversations with commercial fishermen in several locales indicates that there have, at times, been regulations in place that protect the açu variant while the paca variant remained available for commercial harvest. These regulations can now be seen to have had no management value. The results of this study clarify the nature of $C$. temensis color pattern variation and serve to correct previously held assumptions that may have hindered the creation of successful management plans. Perhaps, by recognizing the variants as a single species and by designing management plans in concert with its life history and population dynamics, Cichla temensis, like other species with value in both sportfishing and commercial markets, can be effectively managed and protected.

\section{Acknowledgements}

We thank Acute Angling, Inc., Hillsborough, NJ, U.S.A. for providing funding and logistical support. We thank the many patient sportfishermen who willingly and helpfully cooperated with our specimen collection protocols and NG Turismo Ltda., Manaus, AM, Brazil, for providing field personnel. Special gratitude is reserved for F.J. Almir Mendes dos Santos, whose dedication, sharp eyes and carefully performed morphometric measurements ensured accurate data collection. We thank P. Petry of The Nature Conservancy, S. Willis, University of Nebraska and I. Farias, Federal University of Amazonas for their suggestions and guidance. The base map in Fig. 2 is by Marilyn J. Weitzman and is available from the Neotropical Ichthyological Association. Additional assistance was provided by Rutgers University, New Brunswick, NJ, USA; Department of Biology, Federal University of Amazonas, Manaus, Brazil; and the National Institute of Amazon Research (INPA), Manaus. Specimens were collected under permanent license (MMA IBAMA 113251). This is Rutgers University, Institute of Marine and Coastal Sciences Contribution No. 2011-5

\section{Literature Cited}

Avise, J. C. 2000. Phylogeography: The history and formation of species. Cambridge, Harvard University Press. 447p. 
Barlow, G. W. 2000. The cichlid fishes: nature's grand experiment in evolution. Cambridge, Perseus Books. 352p.

Brafield, A. E., and M. J. Llewellyn. 1982. Animal energetics. Glasgow, United Kingdom, Blackie Books. 168p

Braga, R. 1953. Crescimento de tucunaré pinima, Cichla temensis (Humboldt) em cativeiro (Actinopterygii: Cichlidae). Dusenia, IV: 41-47

Chellappa, S., M. R. Camara, and N. T. Chellappa. 2003a. Ecology of Cichla monoculus (Osteichthyes: Cichlidae) from a reservoir in the semi-arid region of Brazil. Hydrobiologia, 504: 267-273.

Chellappa, S., M. R. Camara, N. T. Chellappa, M. C. M. Beveridge, and F. A. Huntingford. 2003b. Reproductive ecology of a Neotropical cichlid fish, Cichla monoculus (Osteichthyes: Cichlidae). Brazilian Journal of Biology 63: 17-26.

Correa, R. O. 1998. Estudo da idade e crescimento de Cichla monoculus, Spix, 1831, (Perciformes: Cichlidae) no Amazonas central, pela analise de estruturas duras.. Unpublished M.Sc. Dissertation, Instituto Nacional de Pesquisas da Amazônia, INPA, Manaus, Brasil. 71p.

Davis, J. I. \& K. C. Nixon. 1992. Populations, genetic variation, and the delimitation of phylogenetic species. Systematic Biology, 41: 421-435.

Donaldson, K. A. \& R. R. Wilson Jr. 1999. Amphi-Panamic germinates of snook (Percoidei: Centropomidae) provide a calibration of the divergence rate in the mitochondrial DNA control region of fishes. Molecular Phylogenetics and Evolution, 13: 208-213.

Excoffier, L. \& H. E. L. Lischer. 2010. Arlequin suite ver 3.5: A new series of programs to perform population genetics analyses under Linux and Windows. Molecular Ecology Resources, 10: 564-567.

Farias, I. P. \& T. Hrbek. 2008. Patterns of diversification in the discus fishes (Symphysodon spp. Cichlidae) of the Amazon basin. Molecular Phylogenetics and Evolution, 49: 32-43.

Farias, I. P., G. Orti, \& A. Meyer. 2000. Total evidence: molecules, morphology, and the phylogenetics of cichlid fishes. Journal of Experimental Zoology, 288: 76-92

Farias, I. P., G. Orti, I. Sampaio, H. Schneider, \& A. Meyer. 1999. Mitochondrial DNA phylogeny of the Family Cichlidae: Monophyly and fast molecular evolution of the Neotropical Assemblage. Journal of Molecular Evolution, 48: 703-711.

Forsberg, B. R., Castro, J. G. D. \& E. Cargnin-Ferriera. 2001. The structure and functioning of the rio Negro ecosystem: Insights from the Jaú Project, p.125-144. In: N. L. Chão, P. Petry, G. Prang, L. Sonneschein, and M. Tlusty, (Eds.). Conservation and Management of Ornamental Fish Resources of the rio Negro Basin, Amazonia, Brazil - Projeto Piaba. Manaus, Brasil, Editora da Universidade do Amazonas, 301p.

Funk, D. J. \& K. E. Omland. 2003. Species-level paraphyly and polyphyly: frequency, causes, and consequences, with insights from animal mitochondrial DNA. Annual Review of Ecology and Systematics, 34: 397-423.

Gomiero, L. M. \& Braga, F. M. S. 2004. Reproduction of species of the Genus Cichla in a reservoir in Southeastern Brazil. Brazilian Journal of Biology, 64: 613-624.

Goodwin, N. B., S. Balshine-Earn \& J. D. Reynolds. 1998. Evolutionary transitions in parental care in cichlid fish. Proceedings of the Royal Society of London, Series B: Biological Sciences, 265: 2265-2272.

Goulding, M., M. Leal Carvallo \& E. G. Ferreira. 1988. Rio Negro - rich life in poor waters. The Netherlands, SPB Academic Publishing, 200p.
Goulding, M., N. J. H. Smith, \& D. J. Mahar. 1996. Floods of Fortune - Ecology and Economy along the Amazon. New York, NY, Columbia University Press, 193p.

Hall, T. 1999. BioEdit: a user-friendly biological sequence alignment editor and analysis program for Windows 95/98/NT. Nucleic Acids Symposium, 41: 95-98.

Hasegawa, M., H. Kishino, \& T. A. Yano. 1985. Dating of the human-ape splitting by a molecular clock of mitochondrial DNA. Journal of Molecular Evolution, 22 :160-174.

Holley M. H., M. J. Maceina, M. Thomé-Souza, \& B. R. Forsberg. 2008. Analysis of the trophy sport fishery for the speckled peacock bass in the Rio Negro River, Brazil. Fisheries Management and Ecology, 15: 93-98

Hudson, R. R. \& J. A. Coyne. 2002. Mathematical consequences of the genealogical species concept. Evolution, 56: 1557-1565.

Jensen, O. P., D. J. Gilroy, Z. Hogan, B. C, Allen, T. R. Hrabik, B. C. Weidel, S. Chandra \& M. J. Vander Zanden. 2009. Evaluating recreational fisheries for an endangered species: a case study of taimen, Hucho taimen, in Mongolia. Canadian Journal of Fisheries and Aquatic Sciences, 66: 1707-1718

Jepsen, D. B., K. O. Winemiller, \& D. C. Taphorn. 1997. Temporal patterns of resource partitioning among Cichla species in a Venezuelan blackwater river. Journal of Fish Biology, 51: 10851108 .

Jepsen, D. B., K. O. Winemiller, D. C. Taphorn \& D. Rodriguez Olarte. 1999. Age structure and growth of peacock cichlids from rivers and reservoirs of Venezuela. Journal of Fish Biology, 55: 433-450

Jobb, G., A. V. Haeseler, \& K. Strimmer. 2004. TREEFINDER: a powerful graphical analysis environment for molecular phylogenetics. BMC Evolutionary Biology, 4: 1-9.

Junk, W. J, M. G. M. Soares and U. Saint-Paul. 1997. The Fish. P. 385-408. In: W. J. Junk (Ed.). The Central-Amazonian Floodplain: Ecology of a Pulsing System, Ecological Studies, Vol. 126. Berlin, Heidelberg, New York. Springer Verlag, 525p.

Kullander, S. O. 2003. Family Cichlidae. Pp. 605-655. In: Reis, R. E., S. O. Kullander \& C. J. Ferraris Jr. (Eds.). Check List of the Freshwater Fishes of South and Central America. Porto Alegre, Edipucrs, 729p.

Kullander, S. O. \& E. J. G. Ferreira. 2006. A review of the South American cichlid genus Cichla, with descriptions of nine new species (Teleostei: Cichlidae). Ichthyological Exploration of Freshwaters 17: 289-398

Lasso, C. A. \& A. Machado-Allison. 2000. Sinopsis de las especies de peces de la familia Cichlidae presentes en la cuenca del rio Orinoco. Claves, diagnosis, aspectos bio-ecologicos e illustraciones. Museo de la Historia Natural la Salle. Instituto de Zoología Tropical, Universidad Central de Venezuela.

Le Cren, E. D. 1951. The length-weight relationship and seasonal cycle in gonad weight and condition factor in the perch (Perca fluviatilis). Journal of Animal Ecology, 20: 201-219.

Lopez-Fernandez, H., K. O. Winemiller \& R. L. Honeycutt. 2010. Multilocus phylogeny and rapid radiations in Neotropical cichlid fishes (Perciformes: Cichlidae: Cichlinae). Molecular Phylogenetics and Evolution, 55: 1070-1086

Marshall, B. G., B. R. Forsberg \& M. J. F. Thomé-Souza. 2007. Autotrophic energy sources for Paracheirodon axelrodi (Osteichthyes, Characidae) in the middle Rio Negro, Central Amazon, Brazil. Hydrobiologia, 596: 95-103

Mayden, R. L. 1997. A hierarchy of species concepts: The denouement in the saga of the species problem, p. 381-424. In: M. F. Claridge, H. A. Dawah, and M. R. Wilson (Eds.). Species: 
The Units of Biodiversity. New York, NY, Chapman and Hall, $439 \mathrm{p}$

Meyer, A., J. M. Morrissey, \& M. Schartl. 1994. Recurrent origin of a sexually selected trait in Xiphophorus fishes inferred from a molecular phylogeny. Nature, 368: 539-542.

Munoz, H., P. A. Van Damme \& F. Duponchelle. 2006. Breeding behaviour and distribution of the tucunaré Cichla aff. monoculus in a clear water river of the Bolivian Amazon. Journal of Fish Biology, 69: 1018-1030

Murphy, B. R., \& D. W. Willis, editors. 1996. Fisheries techniques, $2^{\text {nd }}$ edition. Bethesda, Maryland, American Fisheries Society, 732p.

Myatt, M. J., D. Hartman, A. E. Gray, L. Arico, G. M. Morchower, \& J. Schratweiser,(Eds). 2005. 2005 World Record Game Fishes, Dania Beach, Florida, The International Game Fish Association, 407p.

Posada, D., \& K. A. Crandall. 1998. MODELTEST: Testing the model of DNA substitution. Bioinformatics, 14: 817-818.

Rabelo, H. \& C. A. R. M. Araujo-Lima. 2002. A dieta e o consume de alimento de Cichla monoculus na Amazônia central. INPA. Acta Amazônica, 32: 707-724.

Rodrigues R., L. Carvalho, J. Zuanon \& K. Del-Claro. 2009. Color changing and behavioral context in the Amazonian Dwarf Cichlid Apistogramma hippolytae (Perciformes). Neotropical Ichthyology, 7: 641-646.

Rohwer, S. \& F. C. Rohwer. 1978. Status signaling in Harris sparrows: Experimental deceptions achieved, Animal Behaviour, 26: 1012-1022,

Sambrook, J., E. F. Fritsch, \& T. Maniatis. 1989. Molecular Cloning: A Laboratory Manual. Cold Springs Harbor, NY, Cold Springs Harbor Laboratory Press, 1659p.

Schroder, S., \& T. Zaret. 1979. The adaptive significance of color patterns in Cichla ocellaris. Copeia, 1979; 43-47.

Shennan, M. G., J. R. Waas \& R. J. Lavery. 1994. The warning signals of parental convict cichlids are socially facilitated. Animal Behaviour, 47: 974-976.

Shimodaira, H. 2002. An approximately unbiased test of phylogenetic tree selection. Systematic Biology, 51: 492-508.

Shreck, C.B. \& P. B. Moyle, (Eds.). 1990. Methods for fish biology. Bethesda, Maryland, American Fisheries Society, 684p.

Sioli, H. 1984, Introduction: History of the discovery of the Amazon and research of Amazonian waters and landscapes. P. 1-14, In: Sioli, H. (ed.). The Amazon. Limnology and Landscape Ecology of a Mighty Tropical River and Its Basin. Dordrecht, The Netherlands, Dr. W. Junk Publishers, 762p.
Smith, N. J. H. 1981. Man, Fishes, and the Amazon. New York, NY. Columbia University Press, 180p.

Stiassny, M. L. 1987. Cichlid familial intrarelationships and the placement of the Neotropical genus Cichla. Journal of Natural History, 21: 1311-1331.

Val, A. L. \& V. M. F. de Almeida-Val. 1995. Fishes of the Amazon and their Environment: Physiological and Biochemical Aspect. Berlin, Germany, Springer-Verlag, 224p.

Vander Zanden, M. J., L. N. Joppa, B. C. Allen, S. Chandra, D. Gilroy, Z. Hogan, J. T. Maxted \& J. Zhu. 2007. Modeling spawning dates of Hucho taimen in Mongolia to establish fishery management zones. Ecological Applications, 17: 2281-2289.

Vasconcelos, W. R., M. S. Nunes, P. Reiss \& I. P. Farias. 2005. Different population genetics patterns in two species of peacock bass (Cichla:Perciformes) of tributaries of the Rio Negro. Unpublished poster presentation. Brazilian Ichthyology Society meeting, January, 2005.

Willis S. C., M. S. Nunes, C. G. Montaña, I. P. Farias, \& N. R. Lovejoy. 2007.Systematics, biogeography, and evolution of the Neotropical peacock basses Cichla (Perciformes:Cichlidae). Molecular Phylogenetics and Evolution, 44: 291-307

Willis S. C., M. S. Nunes, C. G. Montaña, I. P. Farias, G. Ortí \& N. R. Lovejoy. 2010. The Casiquiare River acts as a corridor between the Amazonas and Orinoco river basins: biogeographic analysis of the genus Cichla. Molecular Ecology, 19: 1014-1030

Winemiller, K. O. 2001. Ecology of peacock cichlids (Cichla spp.) in Venezuela. Journal of Aquariculture and Aquatic Sciences, 9: 93-112.

Winemiller, K. O., D. C. Taphon, \& A. Barbarino Duque. 1997. The ecology of Cichla (Cichlidae) in two blackwater rivers of southern Venezuela. Copeia, 1997: 690-696.

Zaret, T. M. 1977. Inhibition of cannibalism in Cichla ocellaris and hypothesis of predator mimicry among South American fishes. Evolution, 31: 421-437.

Zaret, T. M. 1980. Life history and growth relationships of Cichla ocellaris, a predatory South American cichlid. Biotropica, 12: 144-157.

Submitted August 9, 2011

Accepted February 4, 2012

Published March 30, 2012 